\title{
Xenograft Model
}

National Cancer Institute

\section{Source}

National Cancer Institute. Xenograft Model. NCI Thesaurus. Code C19812.

An experimental system in which (usually) human tumor cells are transplanted into immunocompromised mice that do not reject human cells; cells may be implanted under the skin or into the organ type in which the tumor originated. These model systems may be used for drug development and studies of molecular biological mechanisms of cancer. 